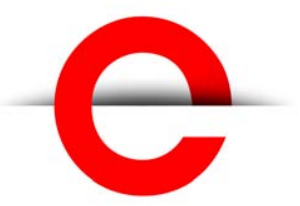

U T S

e P R E S S
PORTAL Journal of Multidisciplinary International Studies

Vol. 17, No. $1 / 2$

Jan 2021

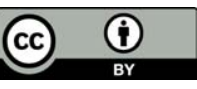

(c) 2021 by the author(s). This is an Open Access article distributed under the terms of the Creative Commons Attribution 4.0 International (CC BY 4.0) License (https:// creativecommons.org/ licenses/by/4.0/), allowing third parties to copy and redistribute the material in any medium or format and to remix, transform, and build upon the material for any purpose, even commercially, provided the original work is properly cited and states its license.

Citation: Mackie, V., Baudinette, T., Chakraborty, M. N., Chan, D., ElfvingHwang, J., Pendleton, M., and Suganuma, K. 2021.

Remembering Romit Dasgupta. PORTAL Journal of Multidisciplinary International Studies, 17:1/2, 155-182. http://dx.doi.org/10.5130/ pjmis.v17i1-2.7470

ISSN 1449-2490 | Published by UTS ePRESS I http://epress. lib.uts.edu.au/ojs/index.php/ portal
ESSAY

\section{Remembering Romit Dasgupta}

\author{
Vera Mackie', Thomas Baudinette ${ }^{2}$, Mridula Nath Chakraborty ${ }^{3}$, Debbie Chan', \\ Joanna Elfving-Hwang ${ }^{5}$, Mark Pendleton ${ }^{6}$, Katsuhiko Suganuma ${ }^{7}$ \\ 1 University of Wollongong \\ ${ }^{2}$ Macquarie University \\ ${ }^{3}$ Monash University \\ ${ }^{4}$ University of Western Australia \\ ${ }^{5}$ University of Western Australia \\ ${ }^{6}$ University of Sheffield \\ 7 University of Tasmania
}

\section{Edited by Vera Mackie}

Corresponding author: Professor Vera Mackie, Honorary Senior Professor, School of Humanities and Social Inquiry, University of Wollongong, Wollongong, NSW 2522, Australia. veraluow.edu.au

DOI: http://dx.doi.org/10.5130/pjmis.v17i1-2.7470

Article History: Received 13/10/2020; Accepted 27/10/2020; Published 28/01/2021

\begin{abstract}
Romit Dasgupta lectured in Japanese Studies at the University of Western Australia until his untimely passing in 2018. He was posthumously awarded the Philippa Maddern Award in 2019 by the University of Western Australia Academic Staff Association. The citation described him as '[p]rofessional, highly organised and respectful to all ...proactive and willing to help others in regard to any issues, consistently demonstrating his passion in supporting his colleagues and students.' In the essays collected here, Romit's friends and colleagues reflect on Romit's qualities and his academic contributions. Romit Dasgupta's work ranged across gender and sexuality studies, queer theory, cultural studies, cultural history, Asian Studies and Asian-Australian Studies. Each of the authors discusses the inspiration they received from Romit Dasgupta's work in these fields.
\end{abstract}

\section{Keywords}

Dasgupta; Gender; Sexuality; Asia; Australia; Migration 
U T S

e PRES S

\section{Preface: The gifts of Romit Dasgupta}

\section{Vera Mackie}

University of Wollongong

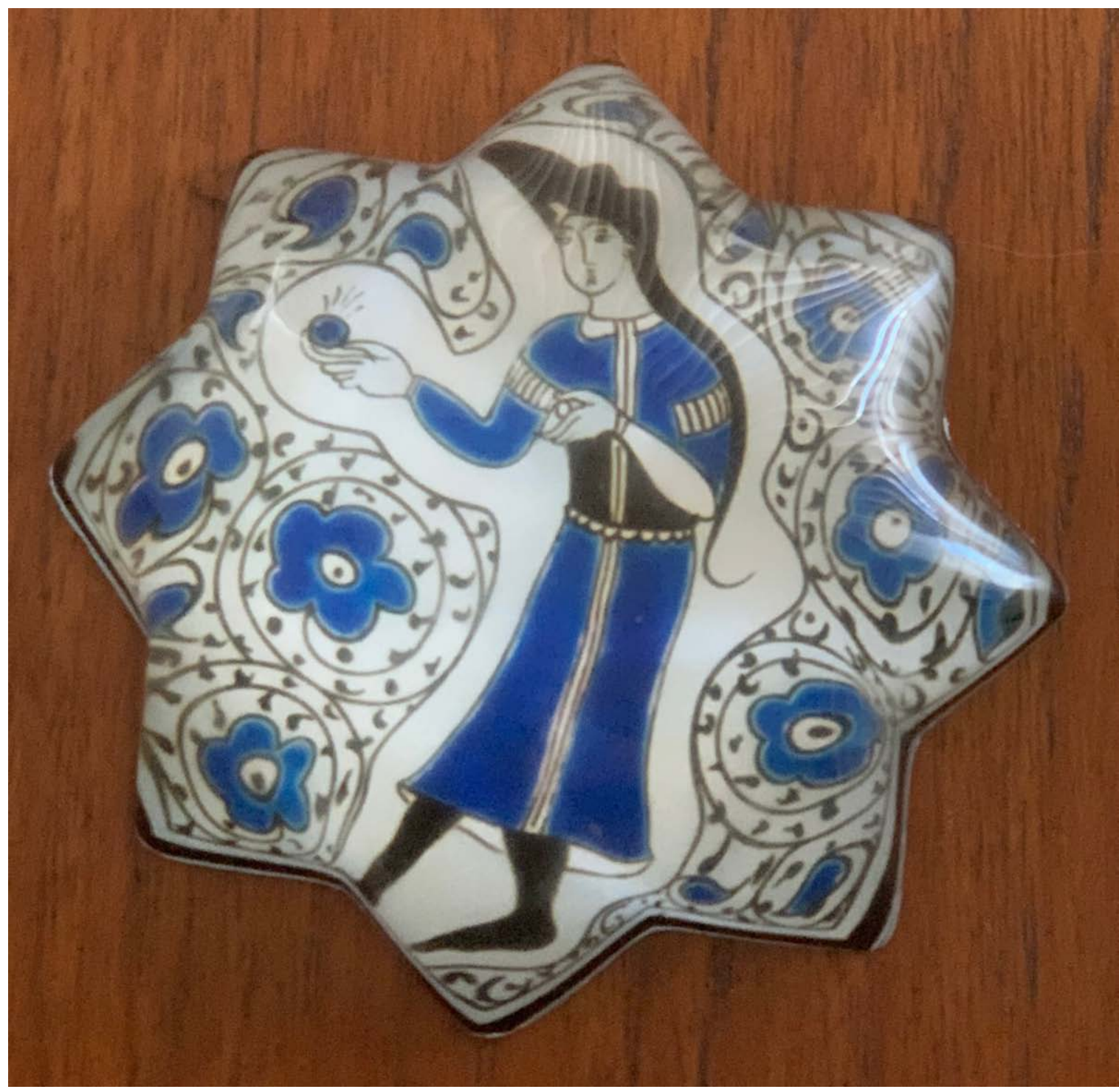

Figure 1. Souvenir paperweight from Turkey; (c) Vera Mackie.

Romit Dasgupta lectured in Japanese Studies at the University of Western Australia until his untimely passing in 2018. He was posthumously awarded the Philippa Maddern Award in 2019 by the University of Western Australia Academic Staff Association. The citation described him as '[p] rofessional, highly organised and respectful to all, ... proactive and willing to help others in regard to any issues, consistently demonstrating his passion in supporting his colleagues and students.' In the essays collected here, Romit's friends and colleagues reflect on Romit's qualities- his gifts. In academic terms, Romit's work ranged across gender and sexuality studies, queer theory, cultural studies, cultural history, Asian Studies and AsianAustralian Studies. He was fluent in Japanese, having majored in Japanese in his first degree, and went on to 
complete a Master's thesis and doctoral dissertation based on research and fieldwork in Japan. His doctoral dissertation formed the basis of his monograph, Re-reading the Salaryman in Japan: Crafting Masculinities (Dasgupta 2013). As can be seen from the essays collected here, Dasgupta's work on masculinities has been hugely influential, well beyond the boundaries of Japanese Studies. In his recent work he was interested in the relationship between Japanese Studies and Turkish Studies, embarking on the study of the Turkish language as an adult and spending time in Turkey as a visiting fellow. In addition to being a gifted scholar, Romit was also gifted in the personal qualities described in the citation above. All of the essays here provide a combination of academic reflection inspired by Dasgupta's work and personal reminiscences of our friendship with Romit. I also cherish many actual gifts from Romit. Both Bengali culture and Japanese practise gift-giving. Over the years Romit would come back from trips with some small gift-Turkish delight; chocolates from Hokkaido; a paperweight from Turkey (pictured above as Figure 1); and, most poignantly, a shawl which had belonged to his beloved mother. Such gifts as these provide a tangible link to my memories of Romit Dasgupta. ${ }^{1}$

\section{Reference}

Dasgupta, R. 2013, Re-reading the Salaryman in Japan: Crafting Masculinities. Routledge, Oxford.

1 These essays developed from a special plenary panel held at the Biennial Conference of the Japanese Studies Association of Australia at Monash University in July 2019. We would like to thank Laura Dales, Beatrice Trefalt and Carolyn S. Stevens for their encouragement and facilitation of this panel. Thanks also to Monash University's technical staff who supported remote participation by some panellists. Samson Soulsby provided invaluable editorial support. Founding editor of PORTAL Paul Allatson encouraged this project and current editors Nick Manganas and Alice Loda steered it through to completion. 


\title{
Dwelling on masculinity studies
}

\author{
Katsuhiko Suganuma
}

University of Tasmania

When people write about Japanese masculinities, they often cite the works of Romit Dasgupta. His name repeatedly appears, almost as if compulsory. As a consequence, people may perceive that works by Dasgupta are all about Japanese salarymen, or the masculinities of those men. But to me, that is somewhat misleading.

Drawing on Raewyn Connell's (2005 [1995]: 77) understanding of Gramscian hegemony, what Dasgupta does is point out that the hegemonic form of salaryman masculinity is always constructed in relation to other forms of subordinate masculinities. In other words, Dasgupta's work aids in our understanding of how not only the dominant but also minoritarian forms of masculinities (or even femininities) are contemporaneously 'crafted' (Kondo 1990: 48). For someone like myself who has looked at minoritarian and queer forms of masculinities, I have always appreciated Dasgupta's forms of analysis, which are intersectional and open-ended.

This intersectional and open-ended nature of Dasgupta's inquiry also provides us with critical insights into understanding some of the complexities involved in the constructions of post-salaryman masculinity. At the end of his monograph, Re-reading the Salaryman in Japan (2013), Dasgupta offers his observations on some alternative forms of masculinities that have assumed a dominant status in recent decades. By way of de-pathologising the qualities of 'otaku,' what may be termed techno-otaku masculinity has now been hailed as the foundation of an identity shared among many who live in what Azuma Hiroki (2009 [2001]: 54) has called a 'database'-centric and individually atomised consumption society. Perhaps related to this phenomenon, critics and scholars alike have referred to the rise of non-'alpha male' masculinity, known in Japan as sōshoku-kei (herbivore) masculinity (Fukasawa 2009; Nihei 2013).

As Dasgupta reminds us at the end of his book, however, the emergence of these alternative forms of hegemonic masculinities does not necessarily represent the liberation and subversion of existing gender and sexual norms (2013: 159). Whether it be techno-otaku masculinity, or herbivore men's masculinity, these alternative masculinities have, as pointed out by other scholars, manifested in response to the demands of a rapidly accelerating socio-economic structure of our time, namely neoliberalism (Condry 2011: 265; Suganuma 2015: 94).

I echo Dasgupta's reservations about treating the rise of techno-otaku masculinity or herbivore masculinity as signs of gender liberation and deconstruction. Upon closer inspection, what is operating underneath the constructions of those alternative masculinities are, more often than not, androcentric concerns and misogyny (Uno 2017: 453, 460; Charlebois 2013: 99-100). Worse still, the rise of these ostensibly 'emancipatory' masculinities has been manipulated by some political figures for the purpose of evoking a sense of nostalgia for past cultures and traditions. Japan's former Prime Minister Abe Shinzō, US President Donald Trump and the proponents of Brexit all exemplify a surrogate 'father' to those who are in fear of uncertainty within neo-liberal states and are in need of resuscitating their allegedly deprived sense of self.

With the breakdown of so-called masculine 'grand narratives,' such as the Cold War, student uprisings, and a championing of capitalist corporate culture, including salaryman masculinity in Japan, we now live in a time when there are no longer any 'big brothers' operating. Database consumption culture (Azuma 2009 [2001]) and its augmented reality (Uno 2017: 75), which has been rapidly enhanced by digital technology, only assist people in looking inward and being concerned about their own self-interest. As Uno Tsunehiro (2011) suggests, we, the 'little' people, now live looking for a fellow 'little brother' in order to create alternative forms of belonging. 
Taking privileges away from their lives may instil fear in many hetero-normative, able-bodied men. Needless to say, such a limit on resources is a common experience among numerous members of gender and sexual minorities. The recent developments of the '\#MeToo' movement and the legalisation of same-sex marriage across many countries put further pressure on a number of heteronormative able-bodied men to question their belonging to the status quo.

Are we having a 'crisis' of masculinity after having lost 'grand narratives'? A sense of crisis comes when one feels out of sync, having stepped out of the designated path without knowing how to get back on track. As Dasgupta discusses in his book, many salarymen that he interviewed already felt that the ideals of corporate masculinity were hard to attain; nothing but fairy tales which were far removed from their own reality (Dasgupta 2013: 45). And yet, many salarymen then still had a perfect ideal male corporate figure whom they could aspire towards becoming. Now that preordained path is lost and has been replaced with several alternatives. Despite the fact that not all of these alternative routes of masculinities are necessarily liberatory or deconstructive, what Indian writer Pankaj Mishra (2018) rightly calls the recent 'frustration and fear of feminisation,' is not merely detrimental to the heteronormative male population. This moment may just provide the necessary opportunity for these men to come to terms with their diverse masculine possibilities-and put themselves in someone else's shoes- the shoes of people whose identities have been undermined due to their minoritarian gender and sexuality.

A little personal anecdote is in order. Romit Dasgupta was my academic mentor as well as a good friend. As his close friend, you could not help but notice that he had a great interest in collecting numerous pairs of shoes. Every time he attended a conference, he went shoe shopping. To be honest, I do not think that he wore all of the shoes that he purchased. But I can only guess that he liked the idea of trying on shoes of different shapes, styles and colours, imagining how he might look in them, and what he could become. He was not afraid of difference and change.

A 'crisis' often occurs when one cannot cope with difference and change. Being afraid of dealing with differences and changes only prompts us to ignore them in order to alleviate the very sense of crisis. For me, then, it is counterproductive to use the term 'crisis' of masculinity to describe the current situation. It is more sensible to suggest that we live in the time of 'confusion' of masculinity. Confusion accompanies multiple ways of being and ways of thinking. Unlike crisis, which more often than not propels fear, confusion allows us to dwell on the moment of reflection and consideration. Take Japan and the United States for example. There is an uncanny coexistence of two types of popular 'little father' or 'mother' figures-Abe Shinzō versus (cross-dresser personality) Matsuko Deluxe in Japan, and Donald Trump versus (drag queen) RuPaul in the United States. Are these popular figures-conservative masculinist politicians on one end of the spectrum, campy gender deconstructive divas on the other-two sides of the same coin? Or, does each represent a competing form of masculinity in the twenty-first century? The discussion of masculinities is complex and confusing. Let us not fear this complexity but dwell on it with patience as Dasgupta (2013: 159) taught us.

Much of Dasgupta's work was concerned with Japan. His scholarship could also, however, have significant implications in any cultural context. The time is ripe for dynamic and intersectional analyses of masculinities across nations. This is not a call for a globalist approach to masculinity studies. It is rather a need for 'connective studies' (Hokari 2007: 15, 18), which attempt to draw productive connections among unexpected subject matters, geopolitics, perspectives and methodologies. I feel that Dasgupta attempted his version of 'connective studies' when he shifted a focal point of his research from Japan to Turkey toward the end of his life. We are left with the seeds he planted. Dasgupta's work has and continues to be an inspiration for expanding our enduring understanding of masculinities in Japan and beyond. 


\section{References}

Azuma, H. 2009 [2001], Otaku: Japan's Database Animals, trans. J. E. Abel \& S. Kono. University of Minnesota Press, Minneapolis. https://doi.org/10.5167/uzh-75429

Charlebois, J. 2013, 'Herbivore Masculinity as an Oppositional Form of Masculinity,' Culture, Society \& Masculinities, vol. 5, no. 1: 89-104. https://doi.org/10.3149/CSM.0501.89

Condry, I. 2011, 'Love Revolution: Anime, Masculinity, and the Future,' in Recreating Japanese Men, (eds) S. Frühstück \& A. Walthall. University of California Press, Berkeley: 262-283.

Connell, R. W. 2005 [1995], Masculinities. Polity, Cambridge. https://doi.org/10.1525/

california/9780520267374.003.0013

Dasgupta, R. 2013, Re-reading the Salaryman in Japan: Crafting Masculinities. Routledge, Oxford.

Fukasawa, M. 2009, Sōshoku Danshi Sedai: Heisei Danshi Zukan [Herbivore Men’s Generation: An Illustrated Guide to the Men of the Heisei Era]. Kōbunsha, Tokyo.

Hokari, M. 2007, 'Mediating on Connective Studies: Indigenous Histories of Australia and Japan in the Era of Globalisation,' in On the Western Edge: Comparisons of Japan and Australia, (eds) M. Tada \& L. Dale. Networks Books, Perth: 15-22.

Kondo, D. K. 1990, Crafting Selves: Power, Gender, and Discourses of Identity in a Japanese Workplace. The University of Chicago Press, Chicago.

Nihei, C. 2013, 'Resistance and Negotiation: “Herbivorous Men” and Murakami Haruki's Gender and Political Ambiguity', Asian Studies Review, vol. 37, no. 1: 62-79. https://doi.org/10.1080/10357823.2012.760528

Mishra, P. 2018, 'The Crisis in Modern Masculinity', The Guardian, 17 March. Online, available: https://www. theguardian.com/books/2018/mar/17/the-crisis-in-modern-masculinity [Accessed 22 June 2020].

Suganuma, K. 2015, 'Queer Cooking and Dining: Expanding Queerness in Fumi Yoshinaga's What Did You Eat Yesterday?,' Culture, Society E Masculinities, vol. 7, no. 2: 87-101.

Uno, T. 2011, Ritoru pīpuru no jidai [The Era of Little People]. Gentōsha, Tokyo. 2017, Bosei no disutopia [Maternal Dystopia]. Shūeisha, Tokyo. 


\title{
Consumption of Japanese gay pornographic films: Erotic salarymen and fantasies of straightness
}

\section{Thomas Baudinette}

Macquarie University

\begin{abstract}
A key theorist within the study of contemporary gender in Japan, Romit Dasgupta was a kind and generous colleague that I had the privilege of first meeting towards the end of my PhD candidature. Since our first meeting at a conference in Adelaide some years ago, Romit provided me with immense support as I navigated my way through the transition from $\mathrm{PhD}$ student into an at times bewildering academic career. Dasgupta's excellent scholarship has been essential to my own work on the gendered politics of Japan's gay culture and I often dialogued with him as I completed my first book manuscript and embarked on new projects. Romit's advice over the brief time that I knew him has greatly shaped my own emerging career within the Japanese Studies community and I wish to pay tribute to his conscientiousness and, above all, to his willingness to mentor early career researchers such as myself. Romit's generosity, his free spirit, and his enquiring mind will continue to live on in the work of all of us that he has mentored. Indeed, his legacy is inscribed into the work of a generation of scholars of Japanese society for whom he represented an intellectual giant, inspiring mentor, and supportive friend. In this brief reflective essay, I draw upon Romit Dasgupta's important study of white-collar masculinity in Japan (2013) to elucidate how pornography contours desires for hegemonic masculinity among young Japanese gay men.
\end{abstract}

Gay pornographic films-known as GV—play a particularly prominent role in influencing young gay men about the nature of their same-sex attraction in Japan. Over the past seven years, I have interviewed men about how media consumption impacts their understandings of their desires. I have also conducted a longitudinal ethnography of Tokyo's gay district of Shinjuku Ni-chōme. It has become increasingly apparent that GV are key texts that young men draw upon to learn about sexuality and gender expression. Indeed, walking along Naka-dōri, the main thoroughfare of $\mathrm{Ni}$-chōme, one is assaulted by pornographic images of men in various stages of undress utilised to advertise the district's gay bars. Encountering pornographic texts is even more common within the stores dotted throughout the district. These adult stores represent one of the major distribution centres for GV. Throughout my ethnography of Ni-chōme it became apparent that coming to browse through these stores' pornographic content is a significant social practice within this gay homosocial space.

Through my ethnography and interviews with approximately fifty young gay men, I learnt that not only is pornography deployed by young men to make sense of the mechanics of sexual behaviour ('learning how to fuck'), but GV also produce a political economy through the privileging of certain body types and gendered performances that strongly impact consumers' understandings of what is and is not desirable ('learning who to fuck and why'). In this brief article, I analyse how the figure of the white-collar worker or 'salaryman' is deployed within Japanese gay pornography as one of many tactics that produce an idealised heterosexual man (or nonke in Japanese gay slang) for gay male consumption. Through interviews with four key informants with the pseudonyms Junho, Yōichi, Haruma, and Shōtarō, ${ }^{2}$ I then elucidate how the consumption of porn has impacted understandings of same-sex attraction by inculcating desires for otokorashisa (manliness) and nonkerashisa (straightness). In so doing, I extend the ground-breaking work of Romit Dasgupta (2013) to reveal that the salaryman plays an integral role in contouring Japanese gay men's

2 These four men were all in their early twenties at the time of first interview and possessed sufficient economic capital to regularly visit $\mathrm{Ni}$-chōme, identifying as middle-class. 
understandings of bodily comportment and style, extending our understandings of this crucial symbol of post-war Japanese masculinity.

Katrien Jacobs, in discussing the potential of internationalised porn studies in the Asian region, has noted that many consumers of pornography in Mainland China and Hong Kong do not 'easily endorse [the] western ideologies or bodily aesthetics' which have become central to porn studies research (2014: 115). That is, Jacobs argues that rather than images of extremely muscular and well-endowed men, Asian consumers of pornography prefer the slender, 'soft' bodies of so-called bishönen (beautiful male youths) (2014: 115). Examining pornographic media produced for women in Japan such as Boys Love (BL) manga, ladies' comics and the films of female-friendly porn company SILK LABO, Jacobs's statement does appear to hold true (see also Mori 2010; Hambleton 2016). Japan's gay pornographic media, however, paints a different picture. When asked to describe the content of GV, for example, both Junho and Yöichi utilised the phrase kin'niku bakuhatsu or 'an explosion of muscle' with reference to the typical physicality of performers. Through analysis of $810 \mathrm{GV}$ films, I discovered that many films do indeed feature men possessing a heavily muscled body (with prominent pectorals and rippling abdominal muscles). This body type is referred to as gatai and is privileged throughout Japan's gay culture as normatively desirable (Baudinette 2017: 520-521). The sex depicted in such films was also often rough and violent, with rape and the uncontrollable nature of men's sexual desire forming a common trope.

Through analysing the promotional material for $810 \mathrm{GV}$ films, I discovered that 95.5 per cent of the films (767/810) only featured models explicitly marketed as nonke, whereas 4.5 per cent (43/810) featured models identifying as gay men. I also uncovered that GV films deployed three specific discourses throughout this corpus to justify why nonke would engage in sex with other men. These three discourses were to emphasise the 'first time' nature of the nonke model's gay sex act to create a sense of adventure; to present the sex act as being 'forced' upon the nonke (often evoking images of rape and pain); and to focus upon the unexpected nature of a nonke's ability to enjoy having sex with men. Throughout the corpus of films, nonke were positioned as objects of desire, privileged as specimens of an ideal masculinity. Discussions with gay men revealed that most regular consumers of GV always already understood GV performers to be amateur straight men. Yōichi explained to me that one of the principal pleasures of watching Japanese gay porn was seeing nonke either 'get fucked' by the GV film company's staff or 'fuck each other' and that this was empowering for gay men who are often positioned as somehow lesser than straight men in society. The passivity of the nonke body within GV thus rendered them commodities, with heterosexuality rendered a symbolic object for gay male consumption.

The overwhelming presence of nonke models in GV has strongly influenced how young gay Japanese men understand their desires, inculcating in many the belief that the nonke represents an ideal sexual partner and subsequently driving them to seek out sexual and romantic partners whom they described as upholding 'nonke characteristics' (nonke no tokuchō). Junho, Yōichi, and Shōtarō particularly expressed a desire to find partners who possessed a nonke's idealised gatai body. Their belief that an ideal nonke would have a gym-trained, muscular gatai body derived from the heteronormative ideologies which circulate throughout the Japanese gay media landscape. This led many Japanese gay men to conflate the bodies they viewed in GV with the notion of nonkerashisa or 'straight-acting nature.' How did this conflation come about? I would argue that the belief that an ideal nonke would possess a gatai body developed due to the common appearance of salaryman characters within GV. Within the corpus of GV films that I analysed, approximately 30.7 per cent (249/810) of the films contained at least one scene where a model explicitly performed the role of a salaryman (often marked through wearing the salaryman uniform of a black suit, white shirt and tie). Promotional images in which salarymen reveal their heavily muscular torsos are common within GV. It is unsurprising that consumers would make links between the salaryman image and a gatai physique within such circumstances. 
In his ground-breaking work on the symbolic role of the salaryman within Japanese society, Romit Dasgupta (2013: 2) persuasively argues that the salaryman has come to embody hegemonic understandings of masculinity in post-Second World War Japan. Throughout his career, Dasgupta traced representations of the salaryman within media (including gay media) and interviewed white-collar workers to paint a picture of the role the salaryman plays in educating Japanese men about what it means to be a man. Dasgupta reveals that the salaryman's ideological positioning as 'bread-winner' (figuratively referred to as daikokubashira, the black pillar which supports the roof of the house) to his wife and children is central to definitions of otokorashisa (masculinity or 'male nature') (46). This promotes a narrative in Japan that 'true' men are active in both the workforce in an economic sense and in the bed in a sexual sense, since the salaryman is intimately tied to the image of the father and husband. That is, as a symbol for ideal fatherhood and as representative of the postwar 'corporate warrior' (kigyö senshi) (Ueno 1995: 215-216), the salaryman image embodies what my informants termed 'nonke characteristics' (nonke no tokuchō).

For my four key informants, the salaryman is more than just a symbolic representation of an ideal masculine 'role.'The salaryman also represented an aesthetic, a bodily comportment or style. The gatai bodies possessed by the models in GV became tied to a fetish for the salaryman as an index for an 'attraction' or akogare for straightness (nonkerashisa) itself. In my work on pornographic consumption among gay Japanese men I have also found an aesthetic within Japan's gay culture that resuscitates hegemonic masculinity within a social space that mainstream society often understands as 'failing' to uphold 'normal' masculine ideals. That is, the prevalence of salarymen in Japanese gay pornography produces ideologies that teach Japanese gay men to fuck men possessing 'nonke characteristics' because such characteristics embody 'normative' masculinity. During interviews, Junho, Yōichi, Haruma and Shōtarō each candidly admitted that consuming GV had indeed inculcated within them a desire to 'fuck straight guys' because their 'masculinity' (otokorashisa) was considered to be both physically attractive and emotionally appealing.

These informants, as well as other gay men I met in Tokyo over the years, explained that watching films and reading comics depicting straight men 'being fucked' represented an important fetish in the Japanese gay culture. Junho, Yōichi, Haruma and Shōtarō explained that they had developed a desire to experience sex with a nonke at least once in their lives through their consumption of GV. The four men's comments resonate quite strongly with the experiences of Hong Kong gay men who subscribe to the so-called 'sissy' sub-culture as reported by Yau Ching (2010). Extrapolating upon her informants' desires to sleep with straight men, Yau Ching notes:

[that] the fantasy to date or have straight boys might be closely akin to a naturalized/socialized desire to access normativity - to be as close to being normal as possible because it is through sleeping with straight boys that one can imagine being close to getting married, having children and building families. Thus, the moment of being closest to normativity is also the moment of confirming the impossibility of one's desire... [it is] the moment of knowing one's queerness. (2010: 3, emphasis in original)

While I doubt that these four men's reported desire to sleep with nonke also indicated a desire to participate in such heteronormative activities as marriage and child-rearing, their fetishised desire for straight men as embodied within the image of the salaryman speaks volumes about how consuming pornography has influenced their understandings of their desires. Moving forward, it will become essential to continue to tease out the role of the salaryman within this process. In so doing, I hope to further extend Romit Dasgupta's work and bring nuance to our understandings of the complexities underlying masculinity in contemporary Japan. 


\section{References}

Baudinette, T. 2017, 'The Spatialization of Desire in a Japanese Gay District Through Signage,' ACME: An International Journal of Critical Geography, vol. 16, no. 3: 500-527. Online, available: https://acme-journal.org/index.php/acme/article/ view/1357 [Accessed 17 September 2019].

Dasgupta, R. 2013, Re-reading the Salaryman in Japan: Crafting Masculinities. Routledge: Oxford.

Hambleton, A. 2016, 'When Women Watch: The Subversive Potential of Female-Friendly Pornography in Japan,' Porn Studies, vol. 3, no. 4: 427-442. https://doi.org/10.1080/23268743.2015.1065203

Jacobs, K. 2014, 'Internationalising Porn Studies,' Porn Studies, vol. 1, nos 1-2:114-119. https://doi.org/10.1080/23268 $\underline{743.2014 .882178}$

Mori, N. 2010, Onna wa poruno o yomu: Josei no seiyoku to feminizumu [Women Read Porn: Women's Desire and Feminism]. Seikyūsha: Tokyo.

Ueno, C. 1995, 'Kigyō senshi-tachi' [Corporate Warriors], in Danseigaku: Nihon no feminizumu bessatsu [Men's Studies: Japan's Feminism Supplement],' (eds) Inoue Teruko, Ueno Chizuko and Ehara Yumiko. Tokyo, Iwanami Shoten: $215-216$.

Yau, C. 2010, 'Dreaming of Normal while Sleeping with Impossible: Introduction', in As Normal as Possible: Negotiating Sexuality and Gender in Mainland China and Hong Kong, (ed.) C. Yau. Hong Kong University Press: Hong Kong: 1-14. https://doi.org/10.5790/hongkong/9789622099876.003.0001 


\section{Researching corporate masculinities in South Korea}

\section{Joanna Elfving-Hwang}

University of Western Australia

In my contribution to this collection of essays I will illustrate the wider currency of Romit Dasgupta's work beyond Japanese Studies. Reflecting on Dasgupta's intellectual contributions in an interdisciplinary and trans-Asian Studies context is particularly fitting as Romit was someone who understood that working together as a community of Asian Studies scholars could only strengthen our country-focused research areas as a whole. He was, however, also sympathetic to Asian Studies colleagues who felt the need to create 'area studies silos.' This was sometimes to ensure that their programs remained country-focused so as not to fall victim to the next institutional restructure seeking to merge 'similar' disciplines, and sometimes because of limits dictated by external funding from national governments which demand a country-specific research focus.

As a scholar, Romit Dasgupta was certainly not wedded to a single geographic context $(1997,2015)$. In fact, over the years working with Romit at the University of Western Australia, I was often struck and inspired by his intellectual curiosity about fields of study that seemed to have very few overlaps with his own and his constant desire to build connections across geographic and disciplinary boundaries. For me, as a UK-educated scholar of Korean Studies where I felt that the boundaries within Asian Studies were sometimes rigidly guarded, Romit's enthusiasm for the intellectual work of his colleagues was not only humbling but also inspirational.

There were many quiet Saturday afternoons when we were both in our offices attempting to catch up on the endless list of outstanding administrative tasks and overdue deadlines. At these times we often wondered why — despite the obvious historical and cultural overlaps and affinities (as well as animosities) that Japan and Korea share-more transnational research projects were not common in our respective fields. We wondered whether our respective academic communities could ever escape these historical legacies. Dasgupta's work on salaryman masculinities is one example where the field of Korean Studies can benefit from a transnational focus. In this essay I will illustrate how Dasgupta's work, and the many corridor conversations I had the privilege to have with Romit over the years, have influenced my own work on South Korean masculinities.

While masculinity studies now exist in South Korea as an area of academic enquiry, the main impetus for the initial development of gender studies in Korea (and by extension in Korean Studies) was the focus on women's rights as workers and as mothers. As academic feminist movements gained foothold in Korean academia from the 1980s, scholars influenced by contemporaneous gender studies scholarship in the US and France began to analyse the place of visual and textual representations of femininity in the patriarchal

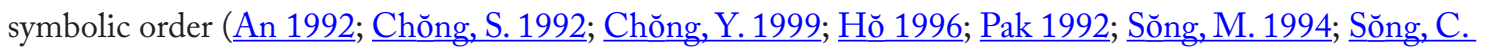
$\underline{1995}$, 1996).

By the 1990s the field of global Korean Studies had no shortage of Korean and non-Korean scholars (myself included) engaged in social, historical, literary and discursive analyses of why patriarchal structures had proved so pervasive in Korea; how these ideas permeated cultural discourses of gender and femininity; and how these influenced individual women in their everyday lived contexts. By contrast, masculinity remained, until recently—as Todd Reeser has observed in the context of European masculinitiesinvisible as an object of academic enquiry beyond providing a discursive structure against which analyses of patriarchal oppression were conducted (2010: 16-21). It was not until Korean scholars began to illustrate how hegemonic masculinities are tied to notions of militarised masculinity and national identity that we have begun to draw the contours of how hegemonic masculinities continue to underlie notions 
of citizenship as a community of men (Choi 1998; Han \& Ling 1998; Moon 1998, 2005). This link between idealised hypermasculinity and authoritarian statehood has been further advanced by other scholars (Murphree 2008). These studies have been helpful in explaining why challenging the continuing patriarchal dividend in the workplace is necessary and also why violence against women's bodies continues to evade appropriate legal consequences in Korea. It also explains why men who aspire to non-heterosexual relationships, or who are uncomfortable with hegemonic notions of militarised masculinity, have been portrayed as non-normative or even deviant in media, identity politics and legal protection of sexual diversity.

Notions about what an ideal (male) worker should look like have been fashioned in and through men's fashion and self-help magazines and books. Since the 1980s these publications have provided guidance for average working men on how to perform corporate masculinity in the workplace in order to maximise their career opportunities. In this respect, what we might call corporate somatic aesthetics have always been recognised as an important part of men's professional identities. These performances of corporate masculinity through clothing and body language have become highly recognisable in popular culture. Some of the most popular recent TV series in Korea feature the travails of hapless corporate soldiers who struggle to hold on to their jobs in the precarious workplace (Elfving-Hwang 2017). The immense popularity of these fictional representations among male viewing audiences attests to how relatable these narratives are.

In the context of my own work on the way in which men embody corporate masculinity in the workplace, Dasgupta's work on salarymen in Japan has been helpful in conceptualising how men negotiate 'ideal' hegemonic masculinities in national and local company culture contexts while rarely being able to entirely measure up to them (2000: 191). Instead, men utilise what Dasgupta refers to as 'a host of individual ontologies of masculinity that engage with the dominant in varying ways' (2000: 191). The corporate cultures within which Japanese salaryman masculinities developed in postwar Japan were not entirely dissimilar to the masculinised (and militarised) corporate cultures of Korea in the 1980s and 1990s. Echoing the corporate soldier in the Japanese imaginary that Dasgupta identifies in his work on the salaryman (2013: 29), the connection between military cultures and company cultures has also played an important role in Korea in constructing corporate masculinities in terms of 'corporate soldiers' fighting for the benefit of the national economy. Furthermore, larger South Korean corporations developed company-specific corporate cultures, manifested in ideas about appropriate corporate attire, ways of addressing colleagues, and values that employees were expected to adhere to (Renshaw 2012: 67; Elfving-Hwang 2020: 146). This corporate culture was effectively used to build a strong sense of belonging to the company as a community of workers. When I embarked on this research project on corporate masculinities in South Korea in 2015, partly inspired by my corridor conversations with Romit, I found that surprisingly little research had been done on how individual Korean men negotiate within corporate cultural and aesthetic expectations and what social meanings they attach to these social practices of the body and presentation of self. I soon discovered during my field research in Korea that the stereotypical corporate 'saellorimaen' is increasingly a thing of the past. Structural changes in workplace practices have meant that most middle-aged men leave (or are forced to leave) corporate employment in their 40 s or are only able to secure short fixed-term contracts. In this context, many of the techniques to enhance a sense of belonging through 'crafting' men to fit into corporate expectations of body language, correct conduct and corporate attire. These formed the company culture (boesa munhwa) that all employees were expected to learn in order to fit in and succeed. These observations resonate with what Dasgupta discovered in his study on how Japanese men responded to the changes in the workplace in the 'post-Bubble' Japan (2000: 190) and illustrate the importance of bodily capital for men in contemporary Korean workplace.

I interviewed 15 men aged 33 to 55 living in the Seoul metropolitan area who all worked or had previously worked in a corporate setting. Some were managers whereas others had not managed to climb the corporate ladder very far before having been offered a redundancy package and joining the growing 
number of men over 40 years of age who are self-employed or under-employed. None of the men felt that they embodied the kind of suave global corporate masculinity that they thought well-paid employees of larger corporations such as Samsung, Hyundai and LG might wish to project on a daily basis. They were all, however, very aware of the need to learn, embody and perform corporate masculinities appropriate to the company culture within which they worked. Most aesthetic labour performed in the workplace contexts was therefore informed by a desire to conform to shared cultural values, and most of the participants expressed anxiety over potential inadvertent transgressions in this respect. Moreover, company culture-specific dress codes intersected with performing heterosexual masculinity in the workplace as a site for producing ideal bodies for the homosocial gaze (and the gaze of their managers in particular), rather than for the admiration of female co-workers. The drivers behind aesthetic labour and specific choices of what aspects of their bodies the participants chose to invest in were seen to be closely linked to bodily capital and often had less to do with neoliberal notions of branding self as a useful 'asset' to the employer. 'Bodily capital' here refers therefore not only to how physical appearance is linked to assumptions of professionalism, knowledge and skills (Bourdieu 1984: 192-193) but also to the ability to utilise everyday somatic etiquette to smooth social relationships in the workplace. The participants explained that projecting youthful vitality through fashionable clothing, a (relatively) fit body, good skin and remedying thinning or greying hair was not considered simply a way to signal continuing ability to work hard to the managers making decisions about the participants' contractual status. More than this, aesthetic labour was seen as a matter of social etiquette in the workplace, through which internal values such as reliability and loyalty could be signalled to enhance social harmony and a sense of belonging. For men in this age group, turning 40 also often meant that they felt anxious about staying 'relevant' and in-touch with concerns and interests of younger workers. For many, then, focusing on maintaining youthful and fit bodies was seen as a 'social lubricant' to ensure that they appeared relevant to and in touch with the world views of their younger colleagues. It is perhaps in this highly social and affective aspect of performing corporate masculinities that comparative studies on both South Korean and Japanese corporate contexts might yield some interesting findings that have the potential to benefit the field of masculinity studies as a whole.

In this short essay I have demonstrated how Dasgupta's intellectual influence is woven into the fabric of my work on corporate aesthetics and the sociology of the body. His influence has not been limited to ideas presented in his publications, but I also benefited from his generous feedback on my work. It was in this dialogue with Romit, and recognising the similarities and transnational flows of ideas (that are often so obvious but all too often not taken advantage of), between South Korea and Japan that my research directions on corporate masculinities in South Korea have taken shape. I am glad that through my work I can in some small way continue to build on his intellectual legacy. Yet above everything else, for all of us who had the good fortune to know Romit Dasgupta, it is his kindness, collegiality and the care that he showed to us all that have left the most valuable legacy to pay forward to future Asian Studies students.

\section{References}

An, S. (ed.). 1995, Han'guk yŏsŏng munhak pip’yŏngnon (한국여성 문학 비평론) [The Theory of Korean Women's Literature]. Kaemunsa, Seoul.

Bourdieu, P. 1984, Distinction: A Social Critique of the Judgment of Taste, trans. R. Nice. Routledge and Kegan Paul, London.

Choi, C. 1998, 'Nationalism and Construction of Gender in Korea,' in Dangerous Women, Gender E Korean Nationalism, (eds) E. H. Kim and C. Choi. Routledge, London: 9-31.

Chŏng, S. 1992, Han'guk munhak gwa yŏsŏngjuŭi pip’yŏng (한국 문학과 여성주의비평) [Korean Literature and Feminist Criticism]. Research Centre for Korean Studies, Seoul. 
Chŏng, Y. 1999, Han'guk p'eminijŭm munhak yŏn'gu (한국 페미니즘 문학 연구) [A Study of Korean Feminist Literature]. Choŭnnal, Seoul.

Dasgupta, R. 1997, 'Thoughts on the Nexus between Japanese Studies and Cultural Studies,' Japanese Studies, vol. 17, nos. 2-3: 4-13. https://doi.org/10.1080/10371399708727626

Dasgupta, R. 2000, 'Performing Masculinities? The “Salaryman” at Work and Play,' Japanese Studies, vol. 20, no. 2: 189-200. https://doi.org/10.1080/713683779

Dasgupta, R. 2013, Re-reading the Salaryman in Japan: Crafting Masculinities. Routledge, Oxford.

Dasgupta, R. 2015, 'Pushing Boundaries: Turkey and the Reframing of Asia and Asian Studies,' Asian Currents: 8-10. http://asaa.asn.au/wp-content/uploads/2015/08/Asian-Currents-February-2015.pdf

Elfving-Hwang, J. 2020, 'Competency as an Embodied Social Practice: Clothing, Presentation of Self and Corporate Masculinity in South Korea,' in Making It Like a Man: Men, Masculinities and the Modern Career, (eds) K. Aarvik \&J. Hoegaerds. Walter De Gruyter GmbH: Berlin: 137-151. https://doi.org/10.1515/9783110651874-008

Elfving-Hwang, J. 2017, 'The Aesthetics of Authenticity: Corporate Masculinities in Contemporary South Korean Television Dramas,' Asia Pacific Perspectives, vol. 15, no. 2: 55-79.

Han, J. \& Ling, L. 1998, 'Authoritarianism in the Hypermasculinized State: Hybridity, Patriarchy and Capitalism in Korea,' International Studies Quarterly, vol. 42, no. 1: 53-78. https://doi.org/10.1111/0020-8833.00069

Hŏ, M. 1996, Han'guk yǒsŏng munhakyŏn'gu (한국여성문학 연구) [A Study of Korean Women's Literature]. T'aehaksa, Seoul.

Moon, S. 1998, 'Begetting the Nation: The Androcentric Discourse of National History and Tradition in South Korea,' in Dangerous Women: Gender and Korean Nationalism, (eds) E. H. Kim \& C. Choi. Routledge, London: 33-66.

Moon, S. 2005, 'Trouble with Conscription, Entertaining Soldiers: Popular Culture and the Politics of Militarized Masculinity in South Korea,' Men and Masculinities, vol. 8, no 1: 64-92. https://doi.org/10.1177/1097184X04268800

Murphree, H. 2008, 'Transnational Cultural Production and the Politics of Moribund Masculinity', positions: asia critique, vol. 16, no. 3: 661-688. https://doi.org/10.1215/10679847-2008-017

Pak, H. (ed.). 1992, Yŏjaro malhagi, momŭro kkŭl ssŭgi (여자로 말하기, 몸으로 글쓰기) [Speaking the Feminine, Writing the Body]. Tto hana ŭi munhwa, Seoul.

Reeser, T. W. 2010, Masculinities in Theory. Wiley-Blackwell: Chichester.

Renshaw, J. R. 2012, Korean Women Managers and Corporate Culture: Challenging Tradition, Choosing Empowerment, Creating Change. Taylor and Francis, Florence.

Song, C. 1996, P'eminijüm pip’yŏng grwa han'guk sosŏl (페미니즘 비평과 한국소설) [Feminist Criticism and the Korean Novel]. Kukhak charyuwǒn, Seoul.

Song, C. 1995, Tasi ssŭnŭn yŏsŏng grwa munhak (다시 쓰는 여성 과 문학) [Rewriting Women and Literature]. P'yŏngminsa, Seoul.

Song, M. 1994, Munhak kwa sŏng ŭi ideollogi (문학과 성의 이 데올로기) [Literature and the Ideology of Gender]. Saemi, Seoul. 


\section{The zero mobo: Erasing the modern boy in interwar Japan}

\section{Debbie Chan}

University of Western Australia

Although Romit Dasgupta left us in July 2018, his academic legacy in the study of gender remains, particularly his work on the Japanese salaryman. Dasgupta wrote extensively on the emergence and crafting of Japanese salaryman masculinity as a hegemonic ideal (2013). In this essay, I consider a form of masculinity which shared continuities with the salaryman discourse in the 1920s and 1930s but eventually disappeared from media use by the late 1930s. I am referring to the figure of the 'modern boy' (modan boit, or mobo), who was generally seen paired with the 'modern girl' (modan gäru, or moga). Unlike the salaryman discourse that continued after the Second World War and grew in cultural prominence and prestige, the modern boy became a relic of the interwar period, at best mentioned today as a nostalgic or artistic symbol of the early decades of the twentieth century (Kaikō 5-toshi mobo moga o sagase! : Hakodate, Niigata, Yokohama, Kōbe, Nagasaki, 2012: 6-7; Mobo moga ga mita Tōkyō, 2018: 8-9; Mizusawa 1998: 5-7; Sakamoto 2003: 1-4; Ātsu 2016: 5).

In the early years of Dasgupta's career researching the salaryman's early twentieth-century origins, he drew continuities between the Japanese salaryman and the modern boy.

On the surface, there may appear to be little in common between the emerging discourse of salaryman masculinity (which appeared to conform to the requirements of the ideology [of the] modernizing nation-state) and the ostensibly non-conformist mobo masculinity. Yet I would argue that in many respects, these two forms of masculinity intersected and overlapped with each other... Both the salaryman and the modern boy were quite clearly products of urban modernityspecifically the urban new middle class. (2004: 73)

Indeed, Dasgupta's documentation of a sketch of the salaryman's flirtation with a waitress presumably at a café (Figure 1) bears resemblance to the sexual frivolity commonly associated with modern boy representations. ${ }^{3}$ Not much more about the modern boy is mentioned in Dasgupta's subsequent works but this insight into the modern boy as a competing form of urban masculinity in connection to salaryman masculinity during Japan's interwar years raises certain questions. If the modern boy was a newly emergent figure of urban masculinity during the interwar years that overlapped with the figure of salaryman, why and how did the modern boy not become a more dominant masculine ideal like the salaryman? Indeed, in the 1920s and 1930s, a definitive distinction between the two was at times impossible. By the 1950s, however, the differences were stark as the post-war hegemonic ideal of salaryman masculinity centred on the fulfilment of the nation-state's agenda via economic productivity (Dasgupta 2013: 29), traits very much in opposition to the non-conformist, non-productive and consumption-focussed modern boy of the 1920s. This was a historical shift in the ideological underpinnings and embodied practices of urban masculinity, reflected in the way the modern boy disappeared into obscurity within a few short years of his emergence.

3 An article in a women's magazine links the modern boy to foreign (Western) influence, romance and sexual flirtation with the modern girl in public spaces such as cafes, train stations and cinema theatres. Fujin gahō [Women's Pictorial], 1 June 1931: 90. 


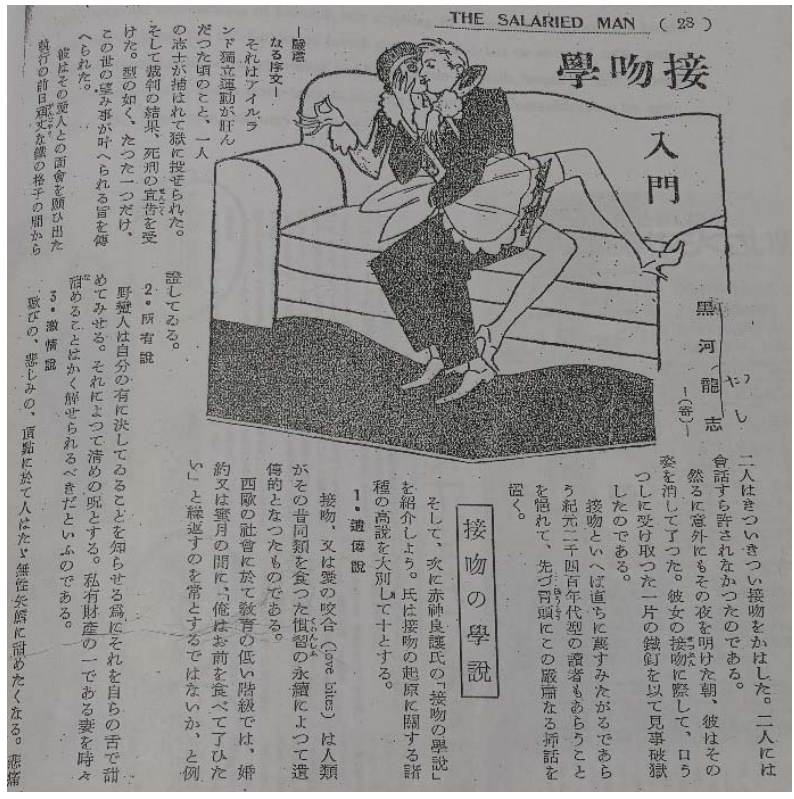

Figure 1. 'The Art of Kissing,' The Salaried Man, 1930, vol. 3, no. 7: 28.

The modern boy's emergence and subsequent disappearance in media discourses therefore need to be analysed as indicative of the changing discourses of gender, modernity and identity during the interwar period. The interwar trajectory of the modern boy provides a certain insight into the processes of gender construction, stigmatisation and erasure in Japanese interwar society. We can trace the power dynamics involved in the social elevation of salaryman masculinity and the erasure of modern boy masculinity, despite overlaps and interconnections between the two. In this brief essay, I touch on deepening anxieties regarding female emancipation and what was seen as 'Western' modernity. These anxieties underpinned many negative portrayals of the modern boy. I explore how the modern boy's erasure as a relevant and socially viable masculinity in interwar Japanese society was discursively engineered and co-opted for the consolidation of a patriarchal and nationalist masculine identity.

\section{The Mobo as a 'Zero'-Deepening Social Anxieties}

Modern boy masculinity was constructed in discourse as introducing new directions for urban masculinity in the vein of the new, the modern, and the emancipatory, but this construction was almost always an ambivalent one. A strong trend of the modern boy discourse was the invalidation of these new directions in the form of parody, derogatory critique and dismissals. ${ }^{4}$ In a roundtable discussion on modernity involving several intellectuals, the modern boy was described as a 'zero,' a 'minus,' and a 'meaningless existence' in that there was no valid justification for the man that he was (Shinchö January 1928: 134-135). In other words, the modern boy was socially invalidated as a viable type of masculinity in interwar Japanese society. Other media sources commenting on the modern boy also reflect this trend, most often in relation to issues of gender and modernity.

\footnotetext{
4 Various sources discussing the modern boy in the late 1920s and early 1930s frame him in terms of mockery and parody. A 1928 article in Shinchō magazine entitled 'Modan seikatsu mandankai' [A Conversation About Modern Life] and a book section entitled 'Modan bōi shōsatsu' [Laughing Off the Modern Boy] in Nanpa dairokkan [The Sixth Sense of Male Seduction] are just two examples that describe him in terms of a humorous dismissal and a parody of masculinity. See Shinchō January 1928: 134-135 and Sakata Toshio 1928: 154-161.
} 


\section{GENDER}

A salient aspect of the modern boy discourse was the notion that the modern boy and modern girl blurred fixed notions of gender. At a time when a female work force was emerging and female progressiveness was celebrated as part of Japan's new modern culture (Harootunian 2000: 9-12, 25), representations featuring the heterosexual dynamic of the moga mobo relationship typically positioned the modern girl as a dominant and threatening woman in antagonistic opposition to an emasculated and feminised/effeminate modern boy. The modern boy therefore was commonly associated with gender ambiguity or cross-dressing tendencies (Figures 2 and $\underline{3}$ ) or depicted as a powerless victim of the modern girl (Figure 4). These illustrations articulate an anxiety regarding what was perceived as a role reversal between the sexes, which needs to be contextualised within the debate surrounding the heterosexual dynamics of power and the apparent emancipation of women in interwar Japanese society.

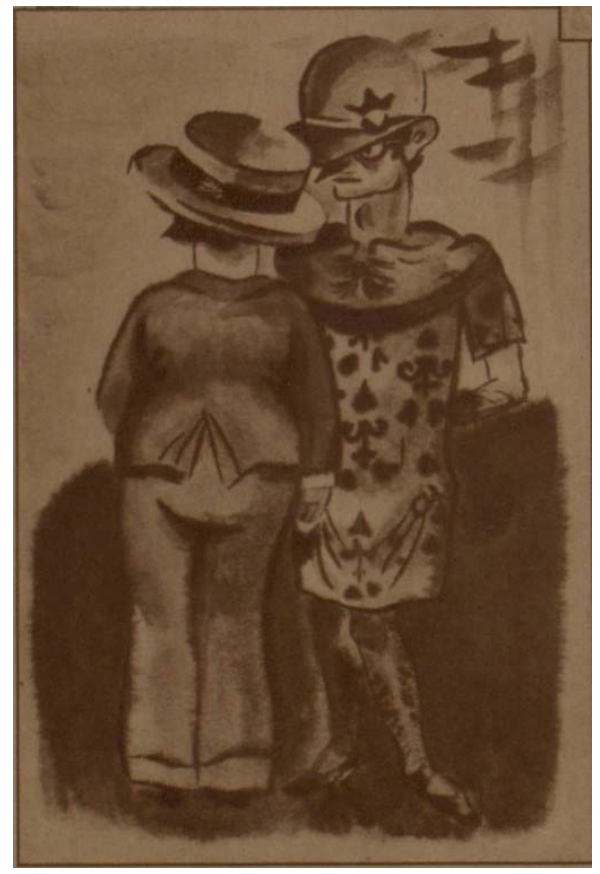

Figure 2. 'Moga mobo fuku no torikae' [Moga Mobo Clothes Swap], Asahi Gurafu [Asahi Graphic], 1928, vol. 11, no. 10: 21 . 
U T S

e PRESS

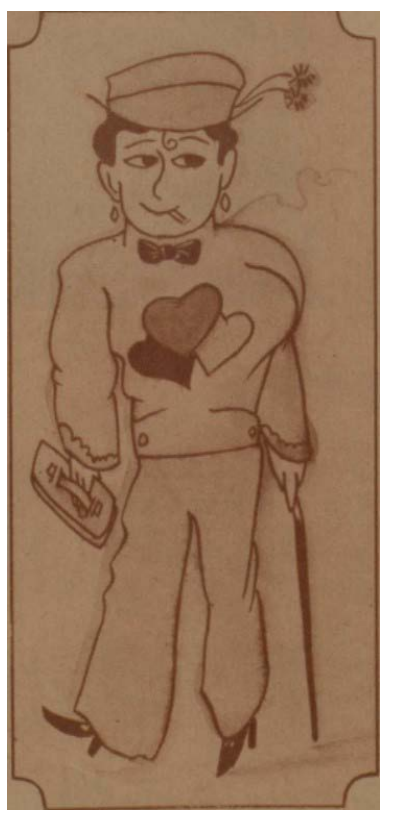

Figure 3. 'Chūsei jinbutsu' [Androgynous Person], Asahi Gurafu [Asahi Graphic], 1928, vol. 10, no. 9: 27. The magazine caption labels this person as a 'mogabo,' a composite figure of the moga and mobo.

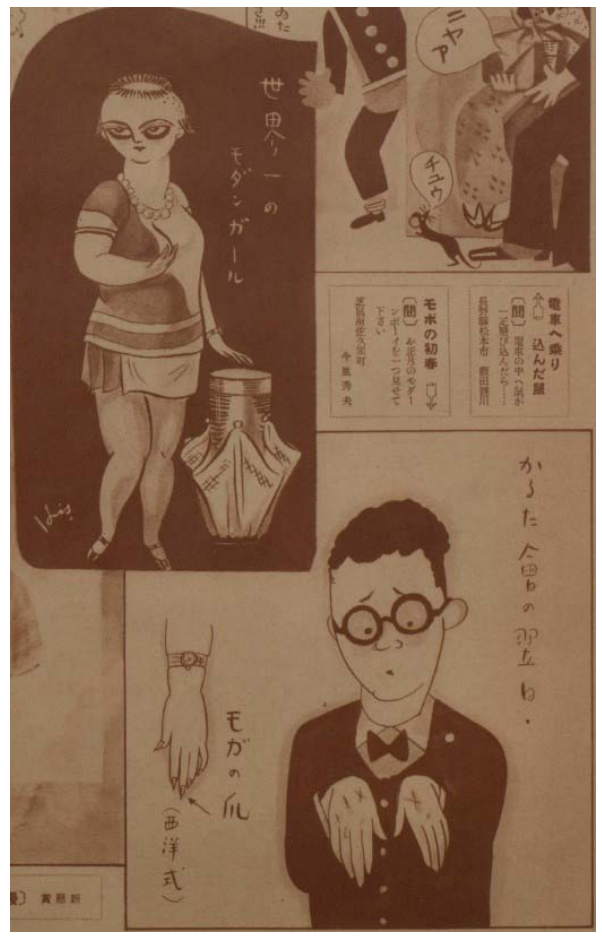

Figure 4. Asahi Gurafu [Asahi Graphic], 1928, vol. 10, no. 2: 8. The threatening figure of the modern girl is juxtaposed with the wounded modern boy who bears scars on his hands from her claw-like fingernails. 
There are two problems with such representations. First, even if the modern boy discourse negotiates alternative meanings of masculinity, these meanings are rejected by 'othering' them as feminine attributes instead of expanding the cultural meanings of masculinity. Secondly, the modern boy in partnership with the more autonomous type of femininity in the modern girl is depicted as non-masculine and in antagonistic opposition to the modern girl as a victim of her domineering aggression. This has significant repercussions on the viability of a feminist type of masculinity in any society that sets up an oppositional binary between the two sexes and subscribes to a zero-sum conception of heterosexual gender relations. When women grow in power and autonomy, it seems, men necessarily diminish. ${ }^{5}$

\section{WESTERN MODERNITY}

Aside from deepening gender anxieties, fashion pictorials depicting the fashionable modern boy and girl in the late 1920s and early 1930s also increasingly express anxieties over a Western modernity that was perceived as incommensurate with interwar Japanese society and identity. A 1929 fashion spread, for example, labels modernity as a 'disease' and modern girls and boys as sufferers of this disease (Figure 5). Essentially, modernity in Japanese society was being fragmented into Western and Japanese constituents that were constructed as oppositional and mutually exclusive. This splitting of modernity and identity into Eastern and Western constituents involves equating Western modernity with the modern girl and boy. The modern boy is presented as a non-indigenous construct: a Westernised, 'foreign' person who needs to be expelled from Japanese society in the consolidation of an authentic Japanese identity.

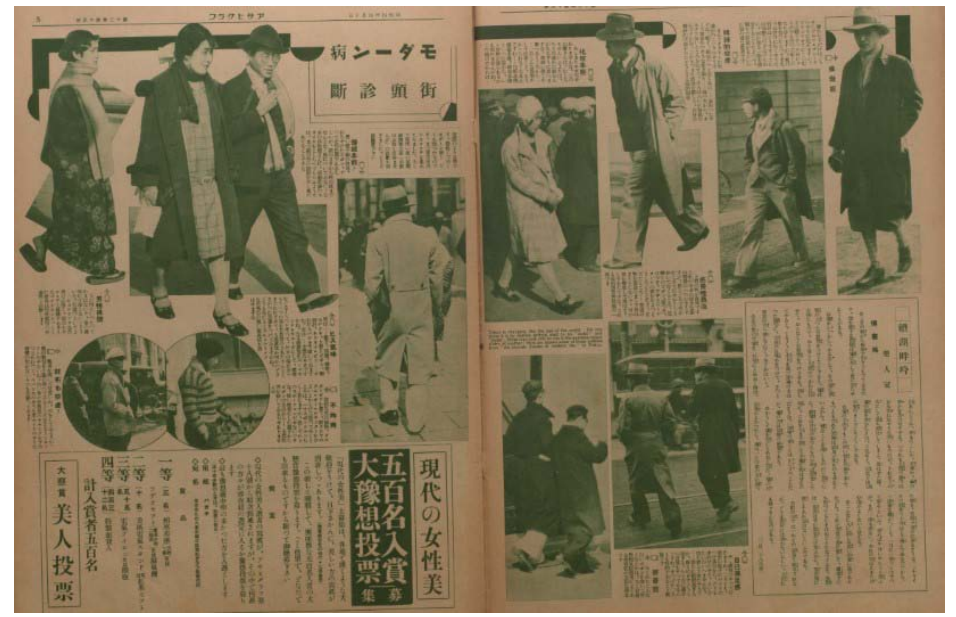

Figure 5. 'Modan-Byō' [Modern Disease], Asahi Gurafu [Asahi Graphic], 1929, vol. 12, no. 15: 4-5. The text reads: 'Tokyo is changing, like the rest of the world. For one thing it is by degrees getting used to its "mobo" and "moga". What may look silly to one is the supreme raison d'être of another! Here are shown some of those suffere[r]s from "the strange disease of modern life" in Tokyo.'

By the 1940s, the modern boy term seems to have disappeared from media use. Fashion spreads and articles on the modern boy were replaced by an emergent nationalistic and militarised youth ideal associated with bodily regulation, patriotism, self-sacrifice and the technological advancements of modern warfare (Figure 6). The erasure of modern boy masculinity did not start in the 1940s. It was there from the very

5 On the difficulties and potentialities of a feminist masculinity that is in support of feminist objectives, see Kimmel (1987), Gardiner (2002) and Wiegman (2002). For a recent study exploring the concept of a zero-sum perspective of gender, see Ruthig et al. (2017). 
beginning of the modern boy's emergence in Japanese society, when the new ideas of masculinity he represented were increasingly denounced, so much so that few people, if any, self-identified as one. ${ }^{6}$

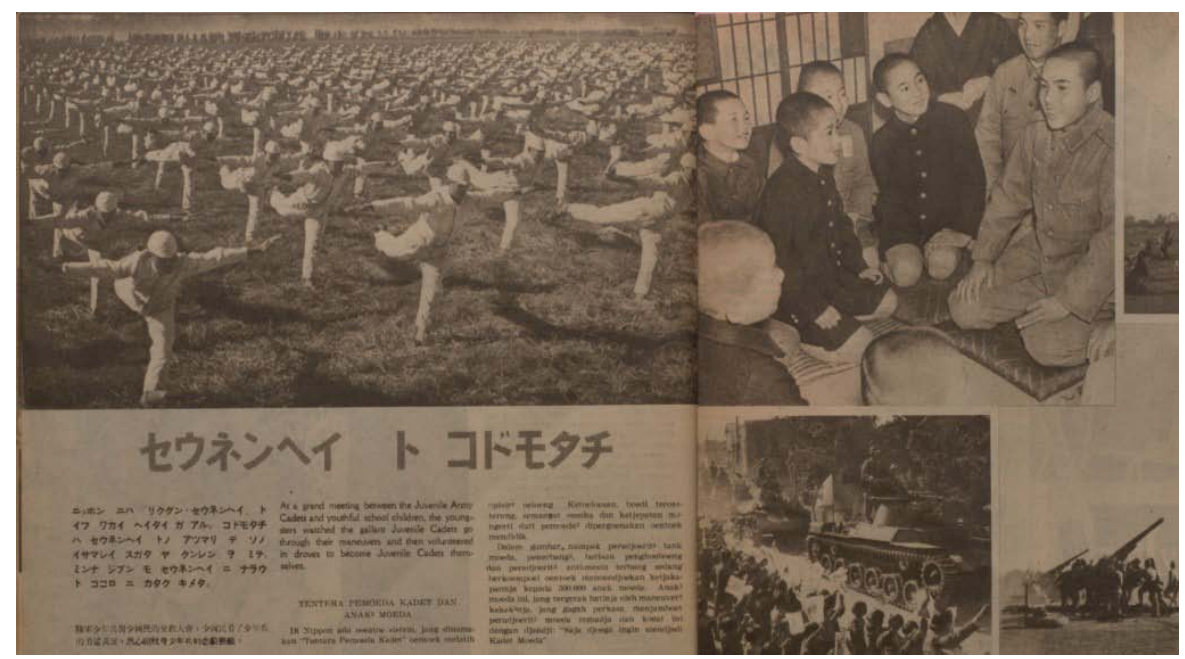

Figure 6. 'Shōnen-Hei to Kodomotachi' [Youth Soldiers and Children], Taiyō [The Sun], 1944, vol. 3 , no. 1: 10-11.

\section{A Closing in Remembrance}

I started this essay with a question arising from Dasgupta's work on the Japanese salaryman - how and why did the modern boy discourse diverge so far from the hegemonic ideal of the salaryman when both seemed to have similar points of origin? In the exploration of the modern boy in terms of his eventual erasure as a relevant and socially viable masculinity in interwar Japanese society, I have argued that social anxieties in the interwar period constructed the 'modern boy' as a negative example of a modern man, ensuring his marginalisation and subordination to other masculinities such as the salaryman or the soldier. It is Dasgupta's work on the crafting of the salaryman as a hegemonic ideal that constantly reminds me of the politics at work in processes of gender construction. This invites my line of questioning on the role that alternative masculinities such as the modern boy play in the reinforcement of a particular ideology of masculinity as hegemonic. My continuing research on the modern boy is in honour of Dasgupta's keen inquiry into the complexities of an interrelated understanding of gender, identity, culture and power.

\section{References}

Asabi Gurafu [Asahi Graphic], 4 January 1928: 8.

.[Asahi Graphic], 22 February 1928: 27.

. [Asahi Graphic], 5 September 1928: 21.

. [Asahi Graphic], 10 April 1929: 4-5.

Ātsu, M. (ed.). 2016, Eien no modan böi: Tanaka Seihyō [The Eternal Modern Boy: Tanaka Seihyō). Suiseisha, Tokyo.

6 The 1928 Shinchō roundtable discussion on modernity, for example, included some tongue-in-cheek comments when the topic of who among the participants was a modern boy. When posed this question, Nii Itaru hesitates on being labelled as a modern boy, before asserting that he is a 'modan nasshingu' (modern nothing). See Shinchō January 1928: 136. 
Dasgupta, R. 2004, Crafting' Masculinity: Negotiating Masculine Identities in the Japanese Workplace, (doctoral dissertation). Curtin University of Technology, Perth.

Dasgupta, R. 2013, Re-Reading the Salaryman in Japan: Crafting Masculinities. Routledge, Oxford.

Fujin gahō [Women's Pictorial). 1 June 1931: 90.

Gardiner, J. K. 2002, 'Introduction,' in Masculinity Studies and Feminist Theory, (ed.) J. K. Gardiner. Columbia University Press, New York: 1-29.

Harootunian, H. 2000, Overcome by Modernity: History, Culture, and Community in Interwar Japan. Princeton University Press, Princeton, New Jersey.

Kaikō 5-toshi mobo moga o sagase!: Hakodate, Niigata, Yokohama, Köbe, Nagasaki [In Search of a Modern Boy-Modern Girl in 5 Port Cities: Hokadate, Niigata, Yokohama, Kobe, Nagasaki]. 2012, BankART, Yokohama.

Kimmel, M. S. 1987, 'Men's Responses to Feminism at the Turn of the Century,' Gender and Society, vol. 1, no. 3: 261-283. https://doi.org/10.1177/089124387001003003

Mizusawa, T. 1998, Mobo moga ten, 1910-1935 [Modern Boy Modern Girl Exhibition: 1910-1935]. Kanagawa kenritsu kindai bijutsukan, Kamakura.

Mobo moga ga mita Tökyō: mono de tadoru Nihon no sekai bunka [Tokyo as Seen by the Modern Boy and Modern Girl: Tracing Japanese Lifestyle and Culture through Things]. 2018, Tabako to shio no hakubutsukan, Tokyo.

Ruthig, J. C., Kehn, A., Gamblin, B. W., Vanderzanden, K., \& Jones, K. 2017, 'When Women’s Gains Equal Men's Losses: Predicting a Zero-Sum Perspective of Gender Status,' in Sex Roles, vol. 76: 17-26. https://doi.org/10.1007/ $\underline{\text { s11199-016-0651-9 }}$

Sakamoto, F. 2003, Tenshin ranman: chichi wa modan bōi datta [Naïve Innocence: My Father was a Modern Boy]. Birudo, Tokyo.

Sakata, T. 1928, Nanpa dairokkan [The Sixth Sense of Male Seduction]. Hihyōsha, Tokyo.

Shinchö [New Tide]. January 1928: 123-147.

Taiyō [The Sun]. 15 January 1944: 10-11.

Wiegman, R. 2002, 'Unmaking: Men and Masculinity in Feminist Theory', in Masculinity Studies and Feminist Theory, (ed.) J. K. Gardiner. Columbia University Press, New York: 31-59. 


\section{Queering grief}

\section{Mark Pendleton}

University of Sheffield

Romit Dasgupta was a mentor and a friend. I first met him at an AsiaPacifiQueer conference in the early 2000s, part of that early wave of queer Asia scholarship in Australia that was hugely inspiring for me as a then undergraduate, but we got to know each other properly after I started studying for a doctorate with Vera Mackie, who had also been Romit's PhD supervisor. Romit later asked me to compile the index for Re-reading the Salaryman in Japan: Crafting Masculinities, his major book-length work and a touchstone for most work on Japanese masculinities since (Dasgupta 2013).

Despite knowing Romit for many years, in the lead-up to the roundtable commemorating his life at the Japanese Studies Association of Australia conference in Melbourne in July 2019, I struggled to get my thoughts together. I would stare blankly at an empty screen for hours. The night before the roundtable I was up all night tossing and turning. This is not my normal, or recommended, pattern of paper preparation. As I was walking into the auditorium, though, it hit me-this may not be my style but it certainly was Romit's. He would regularly slip away from opening night conference receptions to pull an all-night writing session, and then turn up to panels with a sheaf of papers, still making notes as he started to speak. Perhaps my subconscious had been channelling Romit.

There was something else that had been bothering me. I had been hit hard by Romit's passing, partly because it did not happen in isolation. Romit was the sixth queer male friend of mine between the ages of about 35 and 55 who had died within a year or so of each other. These men did not know each other but were all connected to me through varying layers of intimacy and across several spheres of my life. I am a queer man in his forties and a historian who has read lots of queer history. I am just young enough to have missed the worst horrors of the AIDS crisis when the funerals of young men were all too common. The deaths among my friends were clearly just a strange fluke-random accidents and sudden illnesses that took a series of men around my age in what appeared to be a pattern, if only to me. The effect of such a cumulative series of deaths is, though, given our history, inevitably felt more acutely.

As I was thinking about why I had been so affected by Romit's death, and those of the other five, it got me thinking not for the first time about grief and queerness. For many queer people, relationships with birth families can be troubled. They certainly are in my case. Queer people are also well aware of our positions within histories of trauma and exclusion that continue to shape community dynamics. In our best iterations, we collectively hold that pain in our community structures and inter-personal relationships. The writer Cee Frances (2018) described it this way:

If the AIDS crisis has taught us anything, it's that our community absorbs the pain of members far and wide, and exchanges this load generationally by necessity. We feel the loss of strangers through their close proximity to our social orbits, political values and personhood-we grieve, through sharing the stories of their suffering. By remembering, we are reminded of why we must continue fighting current crises.

Frances identifies here an important connection between the retention and distribution of grief and action that is often absent in many heteronormative narratives of grieving, which maintain a sense that the goal of mourning is to compartmentalise and move on. That is a particularly popular cultural reading that we can trace to Freud's distinction between (positive) mourning, a conscious process of letting go of the lost love object, and (unproductive) melancholia, an unhealthy retention of that object in the unconscious (1957). As 
Frances suggests, though, this has never quite worked for queer communities, particularly not once AIDS decimated the community (2018).

The art critic and ACT-UP activist Douglas Crimp is one of many queer thinkers who have grappled with this problem in a number of essays written from the frontlines of the AIDS crisis in the USA (Crimp 2002). In writing back against Lee Edelman's construction of the famous ACT-UP slogan SILENCE=DEATH as the triumph of the literal over the figurative (1989), Crimp argued that the slogan instead serves as a graphic figuration of the demands of a social movement that was contesting the 'facts' of the virus and society's response. Nevertheless, Crimp cautioned that the urgent movement orientation of the politics of the time had some unintended consequences for queer communities, namely that the focus on action prevented a serious consideration of the effect of deaths on us as people and communities: 'We ourselves are silent precisely on the subject of death, on how deeply it affects us' (2002: 130).

In the three decades since Crimp wrote these words, I am not necessarily convinced that we have become any better on the subject of death. Frances praises a community that absorbs pain and distributes it generationally, but that is at best highly differentiated by age and other markers of difference. I wonder in particular if that feeling is as evident for queer people (particularly men) of mine and Romit's age, with decimated generations just above us and vibrant communities forming below. Perhaps my profound sense of loss about these dead friends was a feeling that queer men of our generation sit in between the silences of the past and the promise of better queer futures. There is a feeling that queer deaths remain significant, and necessarily political, but what are we to do in cases of simple human tragedy, with deaths that are mundane and unremarkable in their everydayness, but nevertheless deeply felt?

Sara Ahmed (2004) is another queer thinker who has interrogated this distinction between productive and unproductive mourning, arguing for a queer reclamation of melancholia (something I also tried to do in an essay a decade or so ago about victim activism after the 1995 Tokyo subway gassing [Pendleton 2009]). For Ahmed, the positive aspects of melancholia lie in the fact that it forces the subject to integrate the memory, or better said, the impression of the deceased into their own consciousness-giving the no longer real an existence that lives on through the melancholic.

$[T]$ o lose another is not to lose one's impressions, not all which are even conscious. To preserve an attachment is not to make an external other internal, but to keep one's impressions alive, as aspects of one's self that are both oneself and more than oneself, as a sign of one's debt to others. One can let go of another as an outsider, but maintain one's attachments, by keeping alive one's impressions of the lost other ... To grieve for others is to keep their impressions alive in the midst of their death.

(Ahmed 2004: 160)

Alongside this process of grieving for Romit, I co-edited with Lucy Fraser and Jennifer Coates the Routledge Companion to Gender and Japanese Culture (Coates, Fraser and Pendleton 2020). Our Companion contains forty chapters that seek to map the state of the field of Japanese gender studies - a total of some 225,000 words. Each chapter of about 5,000 words is designed to provide a snapshot of a subfield of gender studies that will be useful both as an introduction to new researchers and for teaching undergraduates.

As we were finalising the manuscript in the period after Romit's death, I was struck again by how important his work has been. He is cited in many of the chapters, on topics ranging from ethnic urban gendered identities to work and the family. The most sustained consideration comes from a chapter explicitly dedicated to him, by the masculinity studies scholar Emma Cook, who positions Dasgupta's work as influential in shaping the field of masculinity studies, as others in this series of essays have also argued. Cook notes in particular Dasgupta's engagement with the work of Raewyn Connell in articulating the ways in which the white-collar male salaried employee at a large company (the 'salaryman') embodies a hegemonic type of Japanese masculinity. This hegemony functions, as Dasgupta and others have argued, to shape the kinds of ways in which men's identities are conceptualised in Japan. 
One of the reasons for such continued reference, even for authors writing about alternative masculinities, is that many people in Japan refer to ideals that are embodied in this figure. In particular, there is a continued focus on male productivity, labour, bread-winning, and specific types of familial responsibility. It thus becomes hard to ignore a figure whose representation is ubiquitous even if not, strictly speaking, particularly common (Cook 2020: 50-51).

So, in thinking about how we can, in Ahmed's words, 'maintain one's attachments, by keeping alive one's impressions of the lost other,' one, perhaps not recommended, option is to adopt Romit's sometimes chaotic paper preparation style. Another is, as several authors tried to do in our Routledge Companion, to re-read and reincorporate Dasgupta's scholarly work into our own thinking about Japan and gender and postwar society. There is also a third way, which is perhaps one that I can leave us with as I circle back to the personal.

In another image of conference attendance Romit can be found at the reception, drink in hand and ensuring that everybody, particularly early-career researchers, know each other. That image of building connections through generosity and kindness - never punching down, but always looking to bring colleagues up - is one that we can all learn from. Romit's legacy, then, will remain in his work-a model of critically-engaged scholarship that will continue to shape the field of masculinity studies for some timebut I hope also in the way we relate to each other in Japanese Studies and beyond. If we can relate with more kindness, more generosity, more, dare I say, love, then we will be keeping the impression of Romit Dasgupta alive in ourselves.

\section{References}

Ahmed, S. 2004, The Cultural Politics of Emotion. Routledge, Oxford. https://doi.org/10.4324/9780203700372

Coates, J., Fraser, L., \& Pendleton, M. (eds). 2020, The Routledge Companion to Gender and Japanese Culture. Routledge, Oxford. https://doi.org/10.4324/9781315179582

Cook, E. 2020, 'Masculinity Studies in Japan,' in The Routledge Companion to Gender and Japanese Culture, (eds) J. Coates, L. Fraser \& M. Pendleton. Routledge, Oxford: 50-59. https://doi.org/10.4324/9781315179582

Crimp, D. 2002, 'Mourning and Militancy,' in Melancholia and Moralism: Essays on AIDS and Queer Politics. MIT Press, Cambridge, MA: 128-149.

Dasgupta, R. 2013, Re-reading the Salaryman in Japan: Crafting Masculinities. Routledge, Oxford.

Edelman, L. 1989. 'The Plague of Discourse: Politics, Literary Theory, and AIDS,' South Atlantic Quarterly, vol. 88, no. 1: 313-314.

Frances, C. 2018, 'On Queer Grieving: The Community Crisis of Vicarious Trauma,' The Lifted Brow, 19 November, Online, available: https://www.theliftedbrow.com/liftedbrow/2018/10/2/on-queer-grieving-the-community-crisis-ofvicarious-trauma-by-cee-frances [Accessed 13 October 2019]

Freud, S. 1957 [1915, 1917] 'Mourning and Melancholia', in The Standard Edition of the Complete Psychological Works of Sigmund Freud, vol. 14, (trans. and ed.) J. Strachey. Hogarth Press, London: 243-258.

Pendleton, M. 2009, 'Mourning as Global Politics: Embodied Grief and Activism in post-Aum Tokyo,'Asian Studies Review, vol.33, no. 3: 333-347. https://doi.org/10.1080/10357820903153731 


\section{Mourning and meaning in the death of the Asian in Australia}

\section{Mridula Nath Chakraborty}

Monash University

I did not know Romit Dasgupta in the way my colleagues write-either personally, or as friend, colleague or mentor in the flesh. My first interaction with Romit was in May 2017. I had recently become National Convener of the Asian Australian Studies Research Network (AASRN) and wished to invite him to AASRN's biennial Asian Australian Identities conference to be held later that year at the Immigration Museum in Melbourne. The theme for that year was Embodiments and Inhabitations. Dasgupta's work on the querying of, and queering in, Asia provided a productive way for re-thinking the diasporic, immigrant and transnational identities associated with Asian Australia. Romit had been an early member of our network, beloved among the Turkish diaspora in Perth due to the work he did on considering that Anatolian outlier as a heuristic in re-conceptualising Asia, and Asian Studies, from its putative margins. He had now moved on to a more specifically Japan-Turkey angle, with Australia remaining more of a conceptual framework for (re-)considering the perimeters of the ideational entity known as 'Asia.' Romit sent me an article of his to explain how he was working with notions of ambivalence, of 'fluid, shifting delineations' and of 'being both a bridge between two worlds and being caught in the faultlines' (Dasgupta 2015: 1-3). As I write in memorium of Romit, I return to these words, ambivalences, bridges, and faultlines.

In January 2018, Nadia Rhook, a colleague from La Trobe University, moved to the University of Western Australia and also took on the position of regional convener for our network. AASRN has existed as a robust and energetic online platform for Asian Australian artists, activists and academics for the last ten years, conceived, nurtured and sustained through the indefatigable efforts of Tseen Khoo and the voluntary labours of its membership. Members also meet up 'in the real world' from time to time in the cities where they reside. On my suggestion, Nadia invited Romit, among others, to gather for the first Perth meet-up she was organising. Again, Romit expressed his inability to participate, not only because the direction of his work had changed, but because he was now in a 'family care-situation' with his father. The next I heard of Romit was that he had had a heart attack and had passed away in the first week of July. To say that the rest of 2018 passed for me under the shadow of this death is an understatement, even though I did not know him long or well enough to warrant such deeply-felt, and unpin-downable, sorrow. Denise Woods, another AASRN member from Perth, confessed to me in an email conversation that she too was extremely shaken by the news. When we posted a note on the AASRN webpage about his passing, numerous members wrote in to speak of Romit's presence and his practices of care for others. So how do I, who had known Romit for so brief a time, remember and honour Romit today?

I have titled this rumination in memoriam as 'Mourning and Meaning in the Death of the Asian in Australia.' Below, I expand on the fragments of signification that I conjure up on what 'dying in a strange country' (Naqvi np) may mean for those marked and 'multicultural' bodies of Asians whose names are usually not legible on gravestones at numerous cemeteries that lie scattered across the span of this settler nation. Bodies that are cremated according to non-mainstream rituals often do not make the same kind of imprint upon its soil, for posterity to claim as signs of inalienable presence, even though memories and writings like this may linger longer in some evanescent archives. Such fugitive ephemera then, from the pages of Facebook, obituary notices, commemorative pieces, correspondences and conversations, may remain as witness and wreath for a life lived, loved and long mourned. In these few words that speak more of inevitable human impermanence, I interleave Dasgupta's work, and what his untimely passing denotes, 
for the fields in which I research, namely diaspora, ethnicities, migrations and postcolonial anti-racist work. To weave my speaking through these fleeting skeins of kinship and friendship that carry on the memory of such lives, I focus mainly on the conceptual framing of transnational, non-biological, self-chosen, queer Asian families that Dasgupta sketched out so poignantly in 2014.

\section{What it Means to Live}

In his essay, 'Queer Imaginings and Travelling of "Family” Across Asia,' Dasgupta uses Arjun Appadurai's concept of 'scapes' to speak to what he terms the 'emotion-scapes.... in relation to imaginings of notions of family and kinship, and the ways in which they traverse borders and scapes, both globally, but more specifically in the context of Asia' (2011: 99). Dasgupta offers readings of three visual media texts: the Japanese television mini-series, Dösōkai [Reunion] (Naitō and Kikuchi 1993), the South Korean film, Bonjijomp'urul hada (Bungee Jumping of their Own) (Kim 2001) and the Singapore/Hong Kong film, Rice Rhapsody (Bi 2005). The essay analyses how normative understandings of traditional family structures are queered across and within Asia, and how they rupture hegemonic Western readings of the concept of family. Dasgupta deploys Gayatri Gopinath's 'scavenger methodology' for research, Julianne Pidduck's concept of the ambivalence that characterises the relationship between family and kin for queers, Ruth Vanita's exploration of the fictive kinship bonds for incorporating a non-family friend/lover into the folds of the family (105) and Tom Boellstorff's 'discursive disconnect between the institution of heterosexual marriage and nonheterosexual identity' (106). The essay 'frames the ways in which queer individuals have carved out spaces, both historically and into the present, within, and in relation to "family" in varied contexts and settings' (102). In doing so, Dasgupta locates himself squarely within a body of diasporic theorising that is part and parcel of the way in which AASRN functions.

Scavenger methodologies of film, fiction, non-fiction, essay, editorial, exhibitions, traditional writing, spoken word, memoirs, one-person shows, curatorships, blogs and vlogs mark the ambivalences of the being and belonging to Asian Australia. They also attest to the fault lines that emerge in the embrace of any identity position when not accompanied by a politics. These and other issues populate AASRN's Facebook pages and offer a genealogy as well as living documentation of its members, and indeed bear testimony to Asian Australian existences. In the face of the innumerable erasures that mark Asian presence in Australia, in its histories, institutions and contributions even today, AASRN provides a running, continuing proof of 'the' contested category of the Asian in Australia. Dasgupta's work and life remains an indelible part of such a fabric and provides a palimpsest of mediated migrant settlement on this unceded Indigenous land. In addition, for me, the citations of a transnational network of South Asian queer theorists in reconceptualising frames of reference for non-normative sexualities is both a validation and an oppositional politics. These inclusions chart a space of queer imaginations and inhabitations that defy hegemonic colonial discourses and continue to offer anti-racist ways of doing academic work, through subversion and a radical questioning of categories, concepts and labels which trouble mainstream ways of thinking about identity in our lives. They also afford pleasures of a chosen subcontinental academic family that coheres around the politics of home.

\section{What it Means to Pass}

Death is the moment when the nation state and normative family structures interrupt and intervene in what is a fundamental human condition. Death and death rites continue to define, and defy, notions of belonging and inclusion in the final analysis. Romit's moment of passing is tabulated in notices on the UWA web pages, in H-Net (Japan) by Vera Mackie, on AASRN's Facebook pages (and perhaps in many other electronic sites), by Bowra and O'Dea's Funeral Services, and by Barbara Hartley's Dedication in Mutual Images. Hartley pays homage to Dasgupta's work, to his warmth, compassion and generosity towards fellow 
scholars, and ends with the following paragraph: 'Romit had a deep and abiding love for his family. He was the very devoted son of Mihir and Mira [both now deceased] and the beloved brother of Arijit (Bapi). We send his family and friends our fondest thoughts and deepest condolences.'

In the fault lines between Romit, the human being, and Dasgupta, the scholar, remains the ambivalence built into an academic career, where one is known, on the one hand, by one's institutional affiliation, alma mater, publications, citations, metrics, student evaluations (and the toll they take), and on the other, by a community of social beings, family, friends, lovers, fellow travellers in the journey of life, all of which remain to remind one of the human being and individual whom loved ones memorialise in obituaries and on online forums. In these all-too brief moments of appearance are embedded a life that is more than a cluster of words. In those days that followed the news of Romit's untimely and unexpected death, I was reminded of queer Indian writer Akhil Katyal's poem (2018 n.p.), 'But who will take care of you in your old age?’: that eternal worry of Asian parents who have accepted the choices their queer children have made, but who still remain tied to conventional ideas of familial blood lines and socially sanctioned families:

"But who will take care of you

in your old age?"

Is the only question my parents ask that actually stumps me.

It's the only one I have stopped finding reasonable-sounding answers to.

I lay down my arms with "I do not know."

Under my breath, I still refuse to treat love as a retirement policy.

But maybe it is just that. Why should I stud it with moons and stars.

Why should I bejewel a simple need.

Maybe all of life does come to "but who will take you to the hospital when you will fall down."

I foreclose the thought under a violet moon.

In those days following Romit's passing, I remained haunted by the thought of his aloneness, though I had no way of knowing if or whether he had indeed been alone at that moment of breath passing out of life. Then in those weeks following Romit's passing, something cropped up on the AASRN Facebook page, which afforded some small comfort and condolence: this was Elizabeth Tan's essay titled 'A Life, Passing' on her father's death, which 'spurred a reflection on growing up Asian Australian' (2018 n.p.). Tan's piece touches upon the connotations of passing as in dying and passing as in obeying the dictats of shibboleth, of knowing what to do when you are moving in and out of closed groups. She speaks of a father born in Singapore, who came to be buried in Midland, Australia, 'in a graveyard much like one he had liked as a boy ... - a peaceful place, he'd said, because all the headstones were the same, uniform heights and shapes' (n.p.). She continues:

My father passes, and over the next month, people come up to me and say that he sponsored this family or that family when they migrated to Australia, that he was the reason they migrated in the first place; they say he paved the way for Asian lawyers in Perth. People talk of my father before he was my father, before he was Charles the migrant—a dockyard worker in his teens, a scruffy longhaired rebel, a ringleader of sit-in protests, a cash-strapped hitchhiker peddling counterfeit watches and blood.

In the case of Romit, I know, as a fellow Bengali speaker and as someone who shares his linguistic-ethnic identity, that he has been cremated, perhaps according to his own wishes stated some time to someone, or according to some understood and recognised Hindu ritual. I have written elsewhere of how migrants who die on alien soil leave no remains behind if they are cremated, whose histories of arrival and genealogies are not apparent immediately from some headstone (Chakraborty 2011). Today, as Australia tries to re-invent itself within an Asian imaginary, the stories of those whose bodies have marked this land, who have left 
behind a legacy of belongingness, nurturance and futuring of Asian Australian possibilities, become all the more important so as to trace genealogies of arrival, living/settling (in all its problematic nuance) and death. In Romit's case, I have to take consolation that he remains, like Tan's father, a bridge between worlds, Indian and Australian, Japanese and Turkish. He remains a beloved incantation on the land that testifies to that old fault line. You belong once and for all when you are interred in the land where you have lived, your arrival and mediated being imprinted on that landscape of imagination for ever. You belong when your work, in print, on students' lives, in communities academic and social, has left behind a legacy such as Romit Dasgupta's.

\section{References}

Appadurai, A. 1990, 'Disjuncture and Difference in the Global Cultural Economy,' Theory, Culture and Society, vol. 7:2: 295-310. https://doi.org/10.1177/026327690007002017

Bi, K. 2005. Rice Rhapsody [alternative title Hainan Chicken Rice]. Hong Kong and Singapore.

Chakraborty, M. N. 2011, 'Leaving No Remains: Death among the Bengalis in Jhumpa Lahiri's Fiction,' South Atlantic Quarterly. Special issue on Death Scenes, (eds) David Ellison \& Katrina Schlunke, vol. 110, no. 4: 813-829.

Dasgupta, R. 2015, 'Pushing Boundaries: Turkey and the Reframing of Asia and Asian Studies,' Asian Currents, February 15: n. p.

Dasgupta, R. 2014, 'Queer Imaginings and Travelling of "Family" Across Asia' in Queering Migrations: Towards, From and Beyond Asia, (eds) C. Quero, J. N. Goh \& M. Sepidoza Campos. Palgrave Macmillan, New York: 99-121.

Gopinath, G. 2000, 'Queering Bollywood: Alternative Sexualities in Popular Indian Cinema,' in Queer Asian Cinema: Shadows in the Sun, (ed.) A. Grossman. Harington Park Press, New York: 283-297. https://doi. org/10.4324/9781315877174-13

Hartley, B. 2018, 'Dedication,' Mutual Images: Japan and Asia: Representations of Selfness and Otherness. vol. 4: 1-2. https:// www.mutualimages-journal.org/index.php/mi/issue/view/4/Vol4 [accessed 9 November 2020].

Katyal, A. 2018, 'But Who Will Take Care of You in Your Old Age?' The Times of India, 16 September. https:// timesofindia.indiatimes.com/blogs/voices/poetic-licence-but-who-will-take-care-of-you-in-your-old-age/

Kim, D. 2001. Bungee Jumping of Their Own (Bonjijopm'urul hadai). South Korea.

Naitō, E. \& Kikuchi, T. 1993, Dösōkai [Reunion], Japan.

Naqvi, T. 2001, Dying in a Strange Country. TSAR: Toronto.

Tan, E. 2018, 'A Life, Passing,' Lenny Letter, August 7. https://www.lennyletter.com/story/what-it-means-to-pass? [accessed 9 November 2020].

Pidduck, J. 2009, 'Queer Kinship and Ambivalence: Video Ethnographies by Jean Carlomusto and Richard Fung,' GLQ: A Journal of Lesbian and Gay Studies, vol. 15, no. 3: 441-468. https://doi.org/10.1215/10642684-2008-031

Vanita, R. 2005, Love's Rite: Same Sex Marriage in India and the West. Penguin Books: New Delhi. https://doi. org $/ 10.1057 / 9781403981608$ 